\title{
Microbiological diagnostics of viral hepatitis
}

\author{
Viral hepatitlerde mikrobiyolojik tanı
}

\section{Ufuk HASDEMIR}

\section{Introduction}

Viral hepatitis is an infection that primarily affects the liver but may also have systemic clinical manifestations. The vast majority of viral hepatitis are caused by one of five hepatotropic viruses: hepatitis A virus (HAV), hepatitis B virus (HBV), hepatitis $\mathrm{C}$ virus (HCV), hepatitis D (delta) virus (HDV), and hepatitis E virus (HEV) (Table I) [1]. HBV, HCV, and HDV also cause chronic hepatitis, whereas HAV does not. HEV causes acute hepatitis in normal hosts but can cause protracted and chronic hepatitis in immunosuppressed patients.

Keywords: Microbiologic diagnosis, Hepatitis A, hepatitis B, Hepatitis C

Table I. Characteristics of five hepatitis viruses and their infections

\begin{tabular}{|c|c|c|c|c|c|}
\hline & HAV & HBV & $\mathrm{HCV}$ & HDV & HEV \\
\hline Family & Picornaviridae & Hepadnaviridae & Flaviviridae & Unassained & Hepeviridae \\
\hline Genus & Hepatovirus & Orthohepadnavirus & Hepacivirus & Delta virus & Hepevirus \\
\hline Nucleic acid & RNA & DNA & RNA & RNA & RNA \\
\hline Incubation period (days) & $15-48($ mean 30$)$ & $30-180$ (mean 60-90) & $15-160($ mean 50$)$ & $30-180$ (mean 60-90) & $14-60$ (mean 40) \\
\hline \multicolumn{6}{|l|}{ Transmission } \\
\hline Fecal-oral & Yes & No & No & No & Yes \\
\hline Sexual & Possible & Yes & Rare & Yes & No \\
\hline Blood & Rare & Yes & Yes & Yes & $\mathrm{No}^{a}$ \\
\hline Chronic infection & No & Yes & Yes & Yes & Yes $^{b}$ \\
\hline $\begin{array}{l}\text { Cirrhosis } \\
\text { HCC }\end{array}$ & No & Yes & Yes & with HBV & $\mathrm{No}^{c}$ \\
\hline
\end{tabular}

${ }^{a}$ Can be bloodborne in endemic areas

${ }^{b}$ Acute hepatitis in normal hosts, protracted and chronic infection only in immunosuppressed patients

${ }^{c}$ Cirrhosis can occur after chronic infection, which is confined to immunosuppressed patients

Liver may also be target some other viruses including Epstein-Barr virus (EBV), cytomegalovirus (CMV), adenovirus, Herpes simplex virus (HSV), enteroviruses,

Ufuk Hasdemir (四)

Department of Microbiology, School of Medicine, Marmara University, and Marmara University Pendik Education and Research Hospital, Istanbul, Turkey

e-mail: ufukhasdemir@marmara.edu.tr yellow fever virus, mumps, rubella, and rubeola. However liver is not the primarily infected organ with these viruses and its' involvement is seen on occasion as part of their systemic infections. Additionally a few viruses such as hepatitis G, hepatitis GB, transfusion-transmitted virus, SEN virus may account in cases of hepatitis presenting features similar to hepatitis caused by well known viruses.

In this section laboratory diagnostics of well known 
hepatitis viruses, HAV, HBV, HCV, HDV, and HEV will be addressed.

\section{Hepatitis A}

Serologic assays: Diagnosis of hepatitis A is most commonly confirmed by detection of specific IgM by an enzyme immune assay based techniques in a single acute-phase serum sample (Figure 1) (Table II, III) [1-3]. IgM Anti-HAV may be detected at the time of the first increase in alanine aminotransferase (ALT). However, specific antibody tests can be initially negative in $10 \%$ of patients who are tested soon after the onset of symptoms; testing should be repated for these patients if hepatitis A is clinically suspected. IgM Anti-HAV can be detected at least 2 days after ALT peak and remains positive in most for 3 to 6 months. It is rarely detected more than years after initial exposure. Assays for total HAV antibody are of little diagnostic value because IgG persists for many years and may be related to a past infection.

HAV antigen and nucleic acid detection: HAV or viral antigen can be detected in the stools of patients 1 to 2 weeks before symptoms develop, but such detection has little value in routine clinical diagnosis because the tests are not widely available and shedding often has stopped before the patient seeks medical attention. Nucleic-acid based techniques are seldom useful for general diagnostic purposes $[1,2]$. These techniques have been used in research laboratories when a sensitive test for the presence of HAV is required.

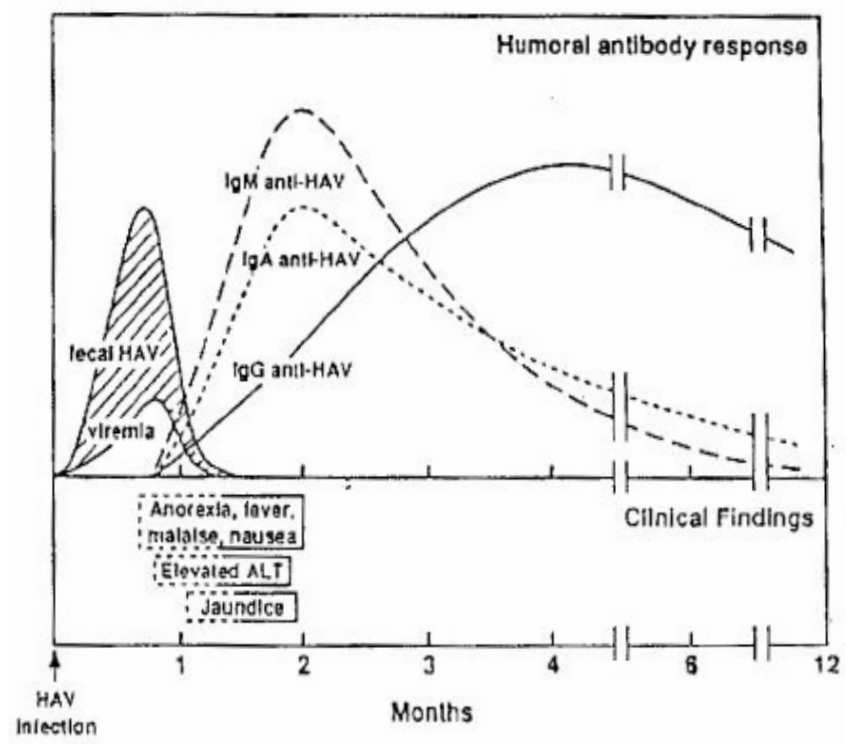

Figure 1. Serologic, virologic and clinical course of hepatitis A
Table II. Simplified diagnostic approach in patients with acute hepatitis

\begin{tabular}{|c|c|c|c|c|}
\hline \multirow[b]{2}{*}{$\begin{array}{l}\text { Diagnostic } \\
\text { interpretation }\end{array}$} & \multicolumn{4}{|c|}{ Serologic tests of patient's serum } \\
\hline & $\mathrm{HbsAg}$ & $\begin{array}{l}\text { IgM An- } \\
\text { ti-HAV }\end{array}$ & $\begin{array}{l}\text { IgM An- } \\
\text { ti-HBc }\end{array}$ & Anti-HCV \\
\hline Acute hepatitis B & + & - & + & - \\
\hline Chronic hepatitis B & + & - & - & - \\
\hline Acute hepatitis A & - & + & - & - \\
\hline $\begin{array}{l}\text { Acute hepatitis A and } \\
\text { B }\end{array}$ & + & + & + & - \\
\hline $\begin{array}{l}\text { Acute hepatitis A and } \\
\text { B (HBsAg below de- } \\
\text { tection threshold) }\end{array}$ & - & + & + & - \\
\hline $\begin{array}{l}\text { Acute hepatitis B } \\
\text { (HBsAg below de- } \\
\text { tection threshold) }\end{array}$ & - & - & + & - \\
\hline Acute hepatitis $\mathrm{C}$ & - & - & - & + \\
\hline
\end{tabular}

$\mathrm{HAV}$, hepatitis A virus; $\mathrm{HBc}$, hepatitis B core; HBsAg, hepatitis $\mathrm{B}$ surface antigen; $\mathrm{HCV}$, hepatitis $\mathrm{C}$ virus

Table III. Methods for detection and identification of hepatitis viruses

\begin{tabular}{lccccc}
\hline \multirow{2}{*}{ Virus } & \multicolumn{2}{l}{ Method } & \multicolumn{3}{c}{} \\
\cline { 2 - 6 } & $\begin{array}{c}\text { Electron } \\
\text { microscopy }\end{array}$ & Culture & $\begin{array}{c}\text { Antigen } \\
\text { detection }\end{array}$ & $\begin{array}{c}\text { Nucle- } \\
\text { ic acid } \\
\text { detec- } \\
\text { tion }\end{array}$ & $\begin{array}{c}\text { Antibody } \\
\text { detection }\end{array}$ \\
\hline HAV & $\mathrm{C}^{c}$ & $\mathrm{C}$ & $\mathrm{C}$ & $\mathrm{C}$ & $\mathrm{A}^{a}$ \\
HBV & $\mathrm{C}$ & $\mathrm{C}$ & $\mathrm{A}$ & $\mathrm{A}$ & $\mathrm{A}$ \\
$\mathrm{HCV}$ & $\mathrm{C}$ & $\mathrm{C}$ & $\mathrm{C}$ & $\mathrm{A}$ & $\mathrm{A}$ \\
$\mathrm{HDV}$ & $\mathrm{C}$ & $\mathrm{C}$ & $\mathrm{B}^{b}$ & $\mathrm{~B}$ & $\mathrm{~A}$ \\
$\mathrm{HEV}$ & $\mathrm{C}$ & $\mathrm{C}$ & $\mathrm{C}$ & $\mathrm{B}$ & $\mathrm{A}$ \\
\hline
\end{tabular}

${ }^{a} \mathrm{~A}$; test is generally useful for the indicated diagnosis

${ }^{b} \mathrm{~B}$; test is useful under certain circumstances

${ }^{c} \mathrm{C}$; test is seldom useful for general diagnostic purposes

\section{Hepatitis E}

Hepatitis E virus may account for as much as $70 \%$ of the cases of acute viral hepatitis in endemic countries. It may cause fulminant hepatitis with case fatality rates of $0,9 \%$ to $2,8 \%$ in men and up to $20 \%$ in pregnant woman. Specific diagnosis of acute or chronic HEV infection remains a challenge. Figure 2. has shown typical serologic and virologic course during HEV infection. Commercially available diagnostic assays vary widely in sensitivity and specificity (Table III) [1,4]. False-positive results may be seen because of high sensitivity of these assays. There is no 
FDA-approved serologic or nucleic acid based techniques for diagnosis of hepatitis E. In HEV nonendemic countries, the infections of more common agents (i.e. HAV, HBV, and $\mathrm{HCV}$ ) should first be excluded. Detection of HEV-specific IgM can be used for serologic diagnosis of acute infection in areas of low prevalence, but comperative studies have shown a wide range of assay performance. Detection of HEV-specific IgG has little impact for diagnosis of acute infection in HEV endemic countries where a majority of population has antibody from prior infection. Specificity of assays is less critical than assay sensitivity in HEV endemic countries. So rapid point-of-care IgM test may have promise for HEV diagnosis in such areas.

Detection of HEV-RNA in serum sample by RT-PCR is used as a confirmatory test for positive IgM anti-HEV results in nonendemic countries and can be used to monitor infection (Table III). Virus isolation by tissue culture and detection of viral antigen are not appropriate methods for diagnostic purposes (Table III).

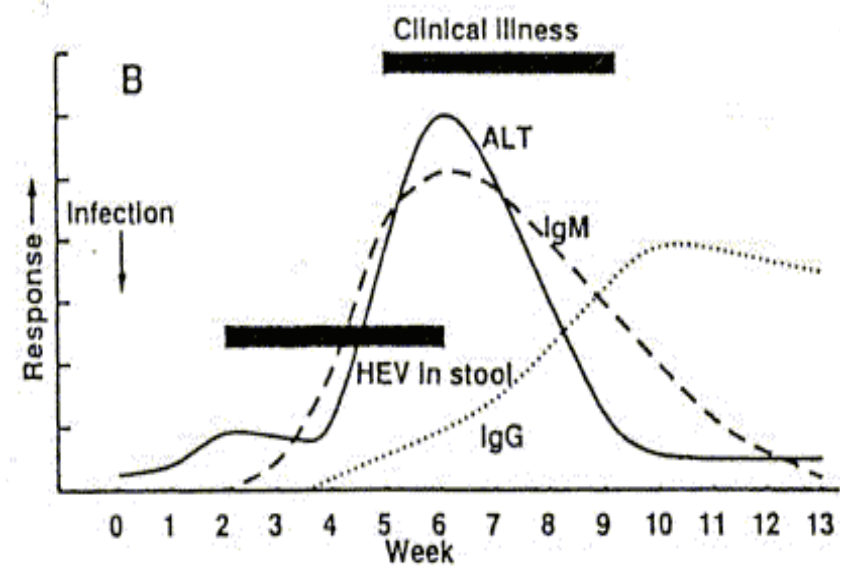

Figure 2. Serologic, and virologic course of hepatitis E

\section{Hepatitis B}

Acute hepatitis B: The diagnosis of acute Hepatitis B is based on the detection of HBsAg and IgM anti-HBc (Figure 3) (Table II, IV) [1,5]. Surface antigen (HBsAg) is the serologic hallmark of HBV infection and is the first marker to appear after acute infection. HBsAg appears in serum within 1 to 12 weeks, usually in 8 to 12 weeks after an acute exposure to HBV, before the onset of symptoms or elevation of serum ALT. In patients who subsequently recover, $\mathrm{HBsAg}$ usually becomes undetectable after 4 to 6 months, followed by development of specific IgM against core antigen (IgM anti-HBc) and then development of $\operatorname{IgG}$ anti-HBc. Anti-HBc can be present weeks to months before detection of anti-HBs (Figure 3). After HBsAg clears, anti-HBs becomes detectable and persists indefinitely. Typically anti-HBs appears in serum as early as 8 months after infection ((Figure 3) (Table II, IV). Markers of viral replication, such as HBsAg and HBV-DNA in the serum, will be present at the same time as anti-HBc. Molecular methods used for HBV-DNA detection has been shown in Table IV. Detection of HBeAg may be useful as a marker for high levels of viral replication and for relative infectivity late in the course of illness. Loss of HBV-DNA, HBeAg, HBsAg and IgM Anti-HBc and the development of anti$\mathrm{HBe}$ and anti-HBs all characterize immunity. The ' $\mathrm{a}$ ' determinant is the predominant $\mathrm{B}$ cell epitope common to all HBV subtypes. Antibodies against to this epitope confer immunity to all HBV subtypes. Anti HBs is sufficient for protection against $\mathrm{HBV}$ infection.

Patients who recover from acute hepatitis B are probably not truly cured of infection because a significant number of patients will have HBV-DNA detectable by PCR many years after clinical recovery. They generally have lifelong protection from disease unless there is significant immunosuppression with loss of protective immune responses, such as in the setting of HIV, chemotherapy, or bone marrow transplantation. Table IV, has shown various serologic profiles during acute hepatitis B infection resulting with recovery.

Recovery from acute infection and Vaccination: Recovery from acute infection and vaccination can be distinguished by testing for total anti-HBc $[1,5]$. Recovery is characterized by the presence of both anti-HBs and total anti-HBc. The presence of anti-HBs is the only marker of $\mathrm{HBV}$ vaccination (Table IV).

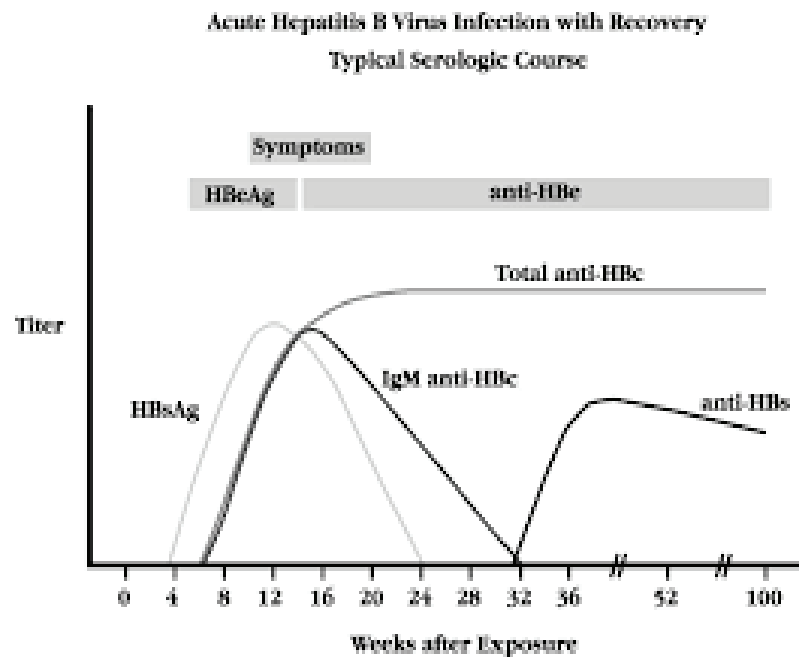

Figure 3. Serologic course of acute hepatitis B infection 
Table IV. Serologic and replication markers in various phases of hepatitis B infection

\begin{tabular}{|c|c|c|c|c|c|c|c|}
\hline & HBsAg & $\mathrm{HBeAg}$ & Anti-HBe & Anti-HBc IgM & Anti-HBc total & Anti-HBs & HBV-DNA \\
\hline \multicolumn{8}{|l|}{ Acute hepatitis B } \\
\hline Early infection & + & - & - & - & - & - & + \\
\hline Acute infection & + & + & - & + & $+/-$ & - & + \\
\hline Windows period & - & - & - & + & $+/-$ & - & + \\
\hline $\begin{array}{l}\text { Acute infection (Recovery } \\
\text { period) }\end{array}$ & - & - & + & + & + & - & + \\
\hline Recovery & - & - & $+/-$ & - & + & + & - \\
\hline \multicolumn{8}{|l|}{ Chronic hepatitis B } \\
\hline $\begin{array}{l}\text { Chronic infection (high } \\
\text { infectivity) }\end{array}$ & + & + & - & - & + & - & + \\
\hline Chronic infection & + & - & + & - & + & - & + \\
\hline Chronic infection & - & - & + & - & + & - & + \\
\hline $\begin{array}{l}\text { Chronic infection (low level } \\
\text { infection) }\end{array}$ & - & - & - & - & + & - & $+/-$ \\
\hline Inactive chronic infection & + & - & - & - & + & - & - \\
\hline Vaccination & - & - & - & - & - & + & - \\
\hline
\end{tabular}

Table V. Nucleic acid based tests for detection of hepatitis viruses

\begin{tabular}{|c|c|c|c|}
\hline Technology & Manufacturer & Product & Targets \\
\hline \multirow{7}{*}{$\begin{array}{l}\text { Polymerase } \\
\text { Chain reaction }\end{array}$} & Abbott & Real-time PCR & $\mathrm{HBV}, \mathrm{HCV}$ \\
\hline & $\begin{array}{l}\text { Molecular Diagnostics } \\
\text { (Abbott Park, IL) }\end{array}$ & & \\
\hline & $\begin{array}{l}\text { Roche } \\
\text { Molecular Diagnostics } \\
\text { Pleasanton, CA) }\end{array}$ & Amplicor & $\mathrm{HCV}$ \\
\hline & & AmpliPrep/COBAS & $\mathrm{HBV}, \mathrm{HCV}$ \\
\hline & & AmpliScreen & $\mathrm{HBV}, \mathrm{HCV}$ \\
\hline & & COBAS TaqMan & $\mathrm{HBV}, \mathrm{HCV}$ \\
\hline & & COBAS TaqScreen & $\mathrm{HBV}, \mathrm{HCV}$ \\
\hline \multirow[t]{2}{*}{$\begin{array}{l}\text { Transcription mediated amplification } \\
\text { (TMA) }\end{array}$} & $\begin{array}{l}\text { Siemens } \\
\text { Healthcare Diagnostics } \\
\text { (Tarrytown, NY) }\end{array}$ & VERSANT & $\mathrm{HCV}$ \\
\hline & Hologic Gen-Probe & Aptima & $\mathrm{HCV}$ \\
\hline Branched DNA amplification (bDNA) & $\begin{array}{l}\text { Siemens } \\
\text { Healthcare Diagnostics }\end{array}$ & VERSANT & $\mathrm{HCV}$ \\
\hline
\end{tabular}


Chronic hepatitis B: Chronic hepatitis B develops in less than $5 \%$ of adults, $10 \%$ to $25 \%$ of young children, and $80 \%$ to $90 \%$ of infants after acute infection. The persistence of HBsAg for more than 6 months is a marker for development of chronic disease (Figure 4) [1,5]. Patients may have additional markers of viral replication, $\mathrm{HBeAg}$ or $\mathrm{HBV}$ DNA, as well. HBeAg and HBV-DNA in serum, should be investigated for further classification of the disease and to determine the need for treatment. Among cases with chronic hepatitis $\mathrm{B}$, a distinction can be drawn between those with highly replicative HBV infection $\left(>10^{5}\right.$ to $\left.10^{6} \mathrm{IU} / \mathrm{mL}\right)$ and those with levels of replication below this threshold. In the relatively replicative phase of chronic hepatitis $B$, levels of HBV-DNA are high, $\mathrm{HBeAg}$ is detectable, $\mathrm{HBcAg}$ in hepatocytes is demonstrable, and clinical markers of liver injury are present. Such patients tend to have moderate to severe chronic hepatitis B. HBV-DNA level in patients having $\mathrm{HBe} A g$ tends to be higher than in those with $\mathrm{HBeAg}$ negative patients. Flares of disease activity may be due to changes in the level of baseline HBV replication. Approximately 10\% to $15 \%$ of persons with highly replicative chronic hepatitis $\mathrm{B}$ lose markers of high replication and undergo spontaneous conversion to a relatively low replicative state characterized by limited infectivity and liver injury and loss of $\mathrm{HBeAg}$ and of detectable HBcAg in hepatocytes. Such patients tend to have clinically mild chronic hepatitis or are even inactive carriers of the virus (Table IV).

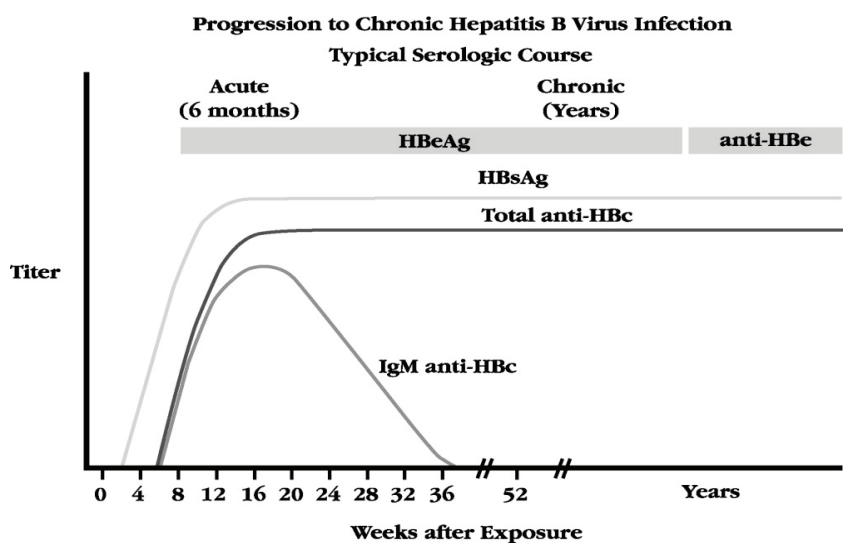

Figure 4. Serologic course in chronic hepatitis B infection

Development of anti-HBe in HBeAg positive patients may occur at any time during chronic infection. Patients with flares of disease activity should be followed for the development of anti-HBe, which indicates control of viral replication. Rising in anti-HBe titers is often accompanied by an increase in serum aminotransferases, followed by a disappearance of $\mathrm{HBeAg}$ and HBV-DNA from the serum and improvement in liver inflammation. However, some patients with active liver disease continue to have HBV-DNA in serum after $\mathrm{HBe} A g$ seroconversion. Unlike hepatitis $\mathrm{C}$, in which any level of virus replication can be associated with liver injury, in chronic HBV infection, a threshold exists, on the order of approximately $10^{3}$ to $10^{6} \mathrm{IU}$ per $\mathrm{mL}$, below which liver injury is negligible or absent. Babies born to mothers with high level of HBV replication (HBeAg positive, HBV-DNA $\geq 10^{6} \mathrm{IU} / \mathrm{mL}$ ) have a $90 \%$ chance for development of chronic HBV infection. Whereas only $10 \%$ or less of babies born to mothers with low level of $\mathrm{HBV}$ replication develops chronic hepatitis B. Inactive hepatitis B carriers who have low level viremia can undergo HBsAg-to-anti-HBs seroconversion. In the setting of immunologic compromise (e.g., cytotoxic chemotherapy, immunusuppresion for organ transplantation, anti-TNF- $\alpha$ therapy, rheumatologic disorders, HIV infection), inactive carriers and even persons who have recovered from heptatitis B can have reactivation. Among the complications of chronic hepatitis B is HCC, postulated to be associated with incorporation of HBV-DNA into the host genome. Recent observations show that, among persons with HBsAg, the risk of HCC resides primarily among those with markers of high level HBV replication. Thus, the level of HBV replication has a profound influence over the clinical expression of chronic hepatitis B.

Additional information regarding HBV-DNA and its' detection have been shown in Box 1, Table IV and Table V $[1,6]$.

Box 1. The role of HBV-DNA quantification in patients with hepatitis B infection

1. HBV-DNA assay plays major role in the evaluation of patients with either $\mathrm{HBeAg}$ positive or $\mathrm{HBeAg}$ negative chronic hepatitis $\mathrm{B}$ to assess candidacy for treatment.

2. Following HBV-DNA is essential to monitor the treatment response in patients with chronic hepatitis $\mathrm{B}$.

3. Distinguishing the window period of acute infection from chronic infection in patients with anti-HBc IgG only as marker of HBV infection.

4. HBV-DNA measurement is also useful in cases of fulminant hepatitis, where there may be undetectable levels of HBsAg.

5. HBV-DNA testing is also indicated in patients in whom there may be false-negative HBsAg, which occurs due to mutants in the surface protein.

6. Several real-time PCR assays have lower limits of sensitivity of approximately $10 \mathrm{IU} / \mathrm{mL}$ and upper limits of $4 \times 10^{9} \mathrm{IU} / \mathrm{mL}$. 
Some people infected with HBV may represent unusual serologic profiles (isolated ant-HBc positiveness, $\mathrm{HBeAg}$ negative mutants, HBsAg escape mutants) as stated in Box 2, Box 3 and Box $4[1,7,8]$.

\section{Box 2. Isolated anti-HBc positiveness}

1. The isolated presence of anti-HBc without other HBV serologic markers are not uncommon. Isolated anti- $\mathrm{HBc}$ is more common in patients with HIV and in those with HCV.

2. Isolated anti-HBc can be only marker of HBV infection in patient during window period.

3. Isolated anti-HBc can be only serologic marker of infection due to a decline of anti-HBs many years after resolution in patients recovered from acute $\mathrm{HBV}$ infection.

4. Rarely, after years of chronic infection with decline of HBsAg to titers below detection limit.

5. Isolated anti-HBc positiveness should be confirmed to exclude false-positive results.

6. Anti-HBc IgM testing should be performed to exclude acute hepatitis if that is suspected.

7. If there are unexplained aminotransferase elevations in a patient with isolated anti-HBc, HBV-DNA testing should be done.

8. Patients having isolated anti-HBc with or without low level HBV-DNA should be considered potentially infectious.

Box 3. Pre-core or HBeAg negative mutants

1. Absence of $\mathrm{HBeAg}$ in a patient having a high level of HBVDNA is typically associated severe liver disease. This is due to the development of $\mathrm{HBV}$ mutants that cannot produce $\mathrm{HBeAg}$ due to mutations in the pre- $\mathrm{C}$ or core promoter.

2. The most frequent pre-C mutation is a $\mathrm{G}$ to $\mathrm{A}$ change at nucleotide 1896, which creates a premature stop codon in the pre- $\mathrm{C}$ region and abolishes production of $\mathrm{HBeAg}$.

3. Pre-C HBV mutants often become dominant viral quasispecies in the viral populations within an individual.

4. $\mathrm{HBeAg}$ negative disease is more frequent with genotypes B, $\mathrm{C}$, and $\mathrm{D}$ than with genotype $\mathrm{A}$ infection.

Box 4. HBsAg escape mutants

1. The mutations (G145R, sD144A) in the ' $a$ ' determinant sequence of HBsAg decrease binding of HBsAg to anti-HBs.

2. These mutations result in development of 'escape' infection in infants infected with HBV following passive-active vaccination.

3. G145R mutation has also been observed in liver transplant recipients who developed recurrent $\mathrm{HBV}$ infection despite HBIG prophylaxis.

\section{Hepatitis D}

Hepatitis D virus (HDV) requires the presence of $\mathrm{HBV}$ for replication. It may either infect the host at the same time as HBV (coinfection), or it can superinfect a host that is already infected with HBV. Simultaneous infection (coinfection) of HBV and HDV generally presents as an acute self-limited hepatitis with full recovery, and chronic infection is seen in $2 \%$ of patients. Whereas chronic hepatitis D generally occurs if a patient with chronic hepatitis B acquires HDV. Chronic hepatitis B is converted to more severe chronic hepatitis after HDV superinfection [1]. Serologically, the diagnosis of hepatitis $\mathrm{D}$ is established by the presence of circulating antibody to HDV (anti-HDV) [1]. IgM antiHDAg antibody develops with acute HDV infection, becoming positive 7-15 days after onset of clinical illness and waning with recovery and resolution of HDV infection (Figure 5). During acute infection, HDV RNA can also be detected by polymerase chain reaction (1). After clearance of HDV, IgG anti-HDAg becomes positive. With chronic $\mathrm{HBV} / \mathrm{HDV}$ infection, both serum IgM and IgG anti-HDAg can be present in conjunction with detectable circulating HDV RNA. In patients with chronic HDV, HDv is the dominant virus because it suppresses HBV replication. Thus, most HBV-HDV coinfected patients have low serum HBVDNA levels. HDV RNA testing can be variable, and falsenegative results occur in actively infected patients. HDV RNA levels do not correlate with the severity of disease or with clinical outcomes. HDV RNA may be most useful in following treatment outcomes rather than in supporting the clinical diagnosis of HDV infection.

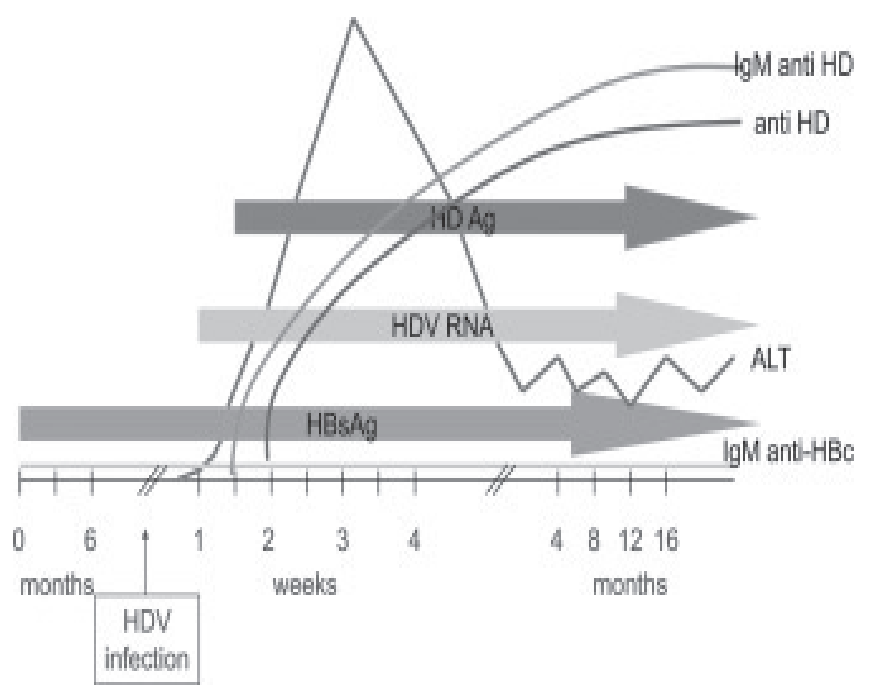

Figure 5. HDV superinfection: serological profile of HDV markers over time in a chronic HBV carrier 


\section{Hepatitis C}

Table I. has shown typical virologic characteristics of $\mathrm{HCV}$ infection. There are at least six major genotypes or clades of hepatitis $\mathrm{C}$ virus (HCV). The high level of virion turnover coupled with the absence of proofreading by the NS5B polymerase results in generation of quasi-species in an infected individual. The incubation period of hepatitis $\mathrm{C}$ is from 15 to 160 days (mean of 60 days). Viremia peaks 8 to 12 weeks after infection and then plateaus or drops to lower levels and persists in $85 \%$ to $90 \%$ of individuals (Figure 5) $[1,9]$. Simplified diagnostic approach in patients with acute hepatitis $\mathrm{C}$ has been shown in Table II. After infection, HCVRNA can be detected within days of exposure. HCV-RNA is found in blood, saliva, tears, seminal fluid, ascitic fluid, and cerebrospinal fluid. The diagnosis of HCV infection is based principally on detection of antibodies to recombinant $\mathrm{HCV}$ polypeptides and by assays for HCV-RNA $[1,9,10]$.

A)

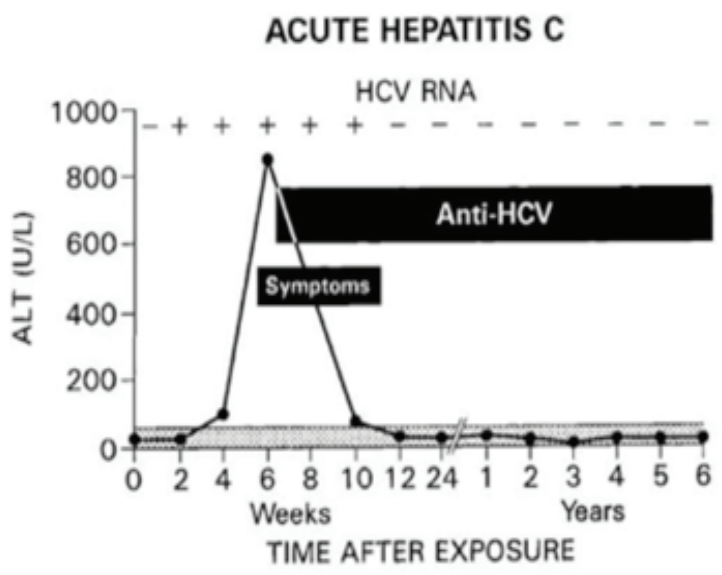

B)

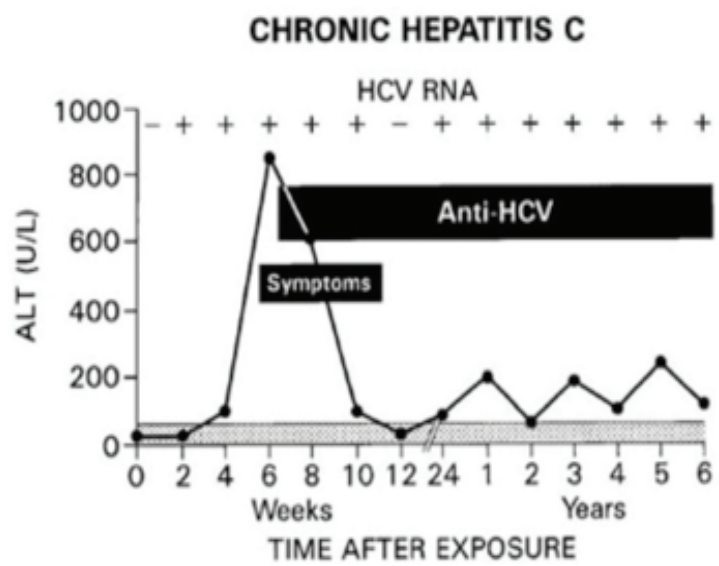

Figure 6. Serologic, biochemical, clinical course of acute (A) and chronic (B) HCV infection
There have been several generations of EIAs that measure antibodies against NS4, core, NS3, and NS5 sequences. The sensitivity of the third-generation EIA is $97 \%$, and it can detect HCV antibody within 6 to 8 weeks of exposure. These assays determine either past or recent $\mathrm{HCV}$ infection, not immunity. Assays for IgM HCV antibodies are not clinically useful. In the past, supplemental serologic testing such as with the recombinant immunoblot assay has been used to improve the specificity of the screening tests. However, supplemental antibody assays are no longer commercially available in the United States. Today, HCV testing recommendations generally call for screening for $\mathrm{HCV}$ antibodies followed by RNA testing [1,9,10]. In acute HCV infection or immunosuppressed states, a negative anti-HCV EIA result does not exclude HCV infection.

$\mathrm{HCV}$-RNA testing is helpful if seronegative acute $\mathrm{HCV}$ infection is suspected because HCV-RNA can be detected within 2 to 3 days after an exposure, while antibodies to $\mathrm{HCV}$ are detectable an average of 7 to 8 weeks later. HCVRNA testing can also be used to screen for $\mathrm{HCV}$ infection in persons with negative anti-HCV EIA results who are known to have conditions associated with diminished antibody production, such as HIV infection and hemodialysis. Various molecular techniques, including reverse-transcription PCR (RT-PCR), real-time PCR, transcription-mediated amplification (TMA), and branched DNA (bDNA) are used for detection of HCV-RNA (Table V). Real-time PCR and TMA assays quantify virus across a wide range and have comparable sensitivity (10 to $50 \mathrm{IU} / \mathrm{mL}$ ) to qualitative assays. In persistently infected persons not receiving treatment, HCV-RNA levels tend to remain stable (within one-half $\log _{10}$ ) over years. In the absence of treatment, there is little need to repeat HCV-RNA tests frequently.

The HCV core antigen titer corresponds closely with the HCV-RNA level, but the test is not widely used in practice $[1,9]$.

Determination of HCV genotype may be useful in predicting the response to therapy (Box 5).

Box 5. Commercially available tests for genotyping of $\mathrm{HCV}$

1. Direct evaluation of $5^{\prime}$ noncoding sequence; Trugene $5^{\prime} \mathrm{NC}$ HCV Genotyping kit (Bayer Healthcare Diagnostics Division, Tarrytown, NY).

2. Hybridization to genotype-specific 5' noncoding oligonucleotide probes; INNO-LiPa HCV II (Innogenetics, Ghent, Belgium).

3. Versant HCV Genotyping Assay 2.0 (Bayer Healthcare Diagnostics Division, Tarrytown, NY). 
Chronic HCV infection is usually diagnosed by testing for $\mathrm{HCV}$ antibodies and then by testing reactive sera for HCVRNA to assess if the infection is ongoing. HCV-RNA level is useful for predicting and monitoring treatment response. Ideally, the quantitative HCV-RNA test should have a sensitivity limit of less than $50 \mathrm{IU} / \mathrm{mL}$. A negative HCVRNA test result $(<50 \mathrm{IU} / \mathrm{mL})$ in an individual found to have antibodies directed HCV (anti-HCV) most likely indicates that $\mathrm{HCV}$ infection has resolved.

\section{References}

1. Dienstag JL, Delemos AS. Viral hepatitis. In: Bennett JE, Dolin R, Blaser MJ, editors. Principles and Practice of Infectious Diseases. 8th ed. Philadelphia: Elsevier, Saunders, 2015: 1439-68.

2. Averhoff F, Khudyakov Y, Bell BP. Hepatitis A virus. In: Bennett JE, Dolin R, Blaser MJ, editors. Principles and Practice of Infectious Diseases. 8th ed. Philadelphia: Elsevier, Saunders, 2015: 2095-112.

3. Hoofnagle JH, Di Bisceglie AM. Serological diagnosis of acute and chronic viral hepatitis. Semin Liver Dis 1991; 11: 73-83.

4. Walsh SR, Hepatitis E virus. In: Bennett JE, Dolin R, Blaser
MJ, editors. Principles and Practice of Infectious Diseases. 8th ed. Philadelphia: Elsevier, Saunders, 2015: 2131-41.

5. Thio CL, Hawkins C. Hepatitis B virus and hepatitis delta virus. In: Bennett JE, Dolin R, Blaser MJ, editors. Principles and Practice of Infectious Diseases. 8th ed. Philadelphia: Elsevier, Saunders, 2015: 1815-39.

6. Iloeje UH, Yang HI, Su J, et al. Predicting cirrhosis risk based on the level of circulating hepatitis B viral load. Gastroenterology. 2006; 130: 678-86.

7. Witt MD, Lewis RJ, Rieg G, Seaberg EC, Rinaldo CR, Thio $\mathrm{CL}$. Predictors of the isolated hepatitis B core antibody pattern in HIV-infected and -uninfected men in the multicenter AIDS cohort study. Clin Infect Dis 2013; 56:606-12.

8. Tong SP, Li JS, Vitvitski L, et al. Evidence for a base-paired region of hepatitis $\mathrm{B}$ virus pregenome encapsidation signal which influences the patterns of precore mutations abolishing HBe protein expression. J Virol 1993; 67: 5651-55.

9. Ray SC, Thomas DL. Hepatitis C. In: Bennett JE, Dolin $\mathrm{R}$, Blaser MJ, editors. Principles and Practice of Infectious Diseases. 8th ed. Philadelphia: Elsevier, Saunders, 2015: 1904-27.

10. Kamili S, Drobeniuc J, Araujo AC, Hayden TM. Laboratory diagnostics for hepatitis $\mathrm{C}$ virus infection. Clin Infect Dis 2012; 55(suppl 1):S43-S48. 